Japan. J. Med. Sci. Biol., 28, 157-164, 1975

\title{
RESPONSES OF CLOSTRIDIUM BOTULINUM TYPE B AND E PROGENITOR TOXINS TO SOME CLOSTRIDIAL SULFHYDRYL-DEPENDENT PROTEASES
}

\author{
Iwao OHISHI, Toshiko OKADA* and GenJi SAKAGUCHI \\ College of Agriculture, University of Osaka Prefecture \\ Sakai-shi, Osaka 591, Japan
}

(Received: February 12, 1975)

\begin{abstract}
SUMMARY: Sulfhydryl-dependent proteases produced by Clostridium botulinum types A, B, and F, Clostridium histolyticum, Clostridium sporogenes and Clostridium perfringens activate preferentially type $\mathbf{E}$ over type $\mathbf{B}$ progenitor toxin but less efficiently than trypsin. The results explain why activable toxin is demonstrable in culture of a strongly proteolytic type B strain.
\end{abstract}

\section{INTRODUCTION}

Activation of Clostridium botulinum type E toxin with an enzyme produced by a proteolytic clostridial strain was first reported by Sakaguchi and Tohyama (1955a, b). Activation is brought about more distinctly by trypsin (Duff, Wright and Yarinsky, 1956) and also by endogenous proteases produced by C. botulinum (Bonventre and Kempe, 1959, 1960; Inukai, 1963; DasGupta, 1971; Holdeman, 1967). DasGupta and Sugiyama (1972a, b) claimed that a trypsin-like enzyme (TLE) isolated from $C$. botulinum type $\mathbf{B}$ strain Okra activates type $\mathbf{B}$ and $\mathbf{E}$ toxins. The toxin of strongly proteolytic type B strain Okra is activable with trypsin even at a late stage of incubation, whereas those of type $\mathrm{A}$ and proteolytic type $\mathrm{F}$ strains are not unless trypsinized at a very early stage of incubation (Bonventre and Kempe, 1959; Holdeman, 1967; Iida, 1970).

Attempts were made to compare the responses of type $\mathrm{B}$ and $\mathrm{E}$ progenitor toxins to sulfhydryl-dependent proteases produced by several strains of proteolytic Clostridia including $C$. botulinum with those to trypsin.

\section{MATERIALS AND METhodS}

Bacterial strains and cultural conditions: For preparation of proteases, $C$. botulinum type A strain Hall, type B strain Okra, and type F strain Langeland were grown at $30 \mathrm{C}$ for $80 \mathrm{hr}$ in the toxin production medium (Kozaki, Sakaguchi and Sakaguchi, 1974). C. histolyticum strain HS-3 and C. sporogenes strain TIS-1,

* Present address: Aichi Prefectural Institute of Public Health, Kita-ku, Nagoya-shi, Aichi 462. 大石 临・岡田敏子・阪口玄二（大阪府立大学農学部獣医公衆衛生学教室, 堺市百舌鳥梅町 4 丁804) 
both given by Dr. S. Kameyama, National Institute of Health, Tokyo, were grown in the same medium at $37 \mathrm{C}$ for 48 and $24 \mathrm{hr}$, respectively. C. perfringens NCTC 8798, given by Dr. H. P. Riemann, School of Veterinary Medicine, University of California, Davis, Calif., was grown also in the same medium at $37 \mathrm{C}$ for $24 \mathrm{hr}$.

For preparation of type B progenitor toxin, strains Okra (proteolytic) and QC (nonproteolytic) were grown in the same medium at $30 \mathrm{C}$ for 30 and $80 \mathrm{hr}$, respectively.

Preparation of clostridial proteases: Whole culture of each strain was added with ammonium sulfate to $60 \%$ saturation. The precipitate was allowed to settle overnight at $4 \mathrm{C}$, collected by centrifugation, and suspended in $0.05 \mathrm{M}$ Tris- $\mathrm{HCl}$ buffer, $\mathrm{pH} 7.5$, containing $10 \mathrm{~mm}$ mercaptoethanol (MCE). The suspension was clarified by centrifugation. The supernatant was applied to a Sephadex G-200 column $(2.5$ by $95 \mathrm{~cm})$ and eluted with the same buffer at room temperature. Each of 5-ml fractions was determined for protein contents, toxicity in case of $C$. botulinum, and protease, amidase and esterase activities by the procedures given below. C. botulinum toxin was separated from the enzyme. The three enzyme activities of all the strains but $C$. perfringens were eluted in a single peak; those of $C$. perfringens in two peaks, named proteases 1 and 2. The fractions containing protease, amidase and esterase activities were pooled, concentrated by ultrafiltration through Amicon membrane UM-10, and stored in the presence of $10 \mathrm{mM}$ MCE in a refrigerator. The activities of the enzyme prepared from each organism are shown in Table I. No lethal activity was demonstrable in $0.01 \mathrm{ml}$ of any of the preparations.

Preparation of the progenitor toxins: The progenitor toxins of both proteolytic C. botulinum type B strain Okra and nonproteolytic strain QC were prepared by the same method. The whole culture was brought to $\mathrm{pH} 4.0$ with $3 \mathrm{~N}$ $\mathrm{H}_{2} \mathrm{SO}_{4}$ and left standing overnight at room temperature. After siphoning off the supernatant fluid, the precipitate was collected by centrifugation, suspended in $0.2 \mathrm{~m}$ phosphate buffer, $\mathrm{pH} 6.0$, and centrifuged. The extract was added with ammonium sulfate to $60 \%$ saturation. The formed precipitate was collected by centrifugation and dissolved in a minimal volume of $0.1 \mathrm{~m}$ acetate buffer, $\mathrm{pH} 6.0$, containing $0.1 \mathrm{~m} \mathrm{NaCl}$. This was applied to a Sephadex G-200 column $(2.5$ by $95 \mathrm{~cm})$

TABLE I

Enzymatic activities of clostridial protease preparations

\begin{tabular}{lccc}
\hline Protease from & $\begin{array}{c}\text { Protease } \\
\text { units/ml* }\end{array}$ & $\begin{array}{c}\text { Amidase } \\
\text { units/ml* }\end{array}$ & $\begin{array}{c}\text { Esterase } \\
\text { units/ml* }\end{array}$ \\
\hline C. histolyticum & 242 & 9.89 & 48.6 \\
C. sporogenes & 160 & 15.3 & 0.34 \\
C. botulinum type A & 220 & 7.60 & 25.3 \\
C. botulinum type B & 125 & 22.0 & 12.6 \\
C. botulinum type F & 116 & 13.6 & 14.0 \\
C. perfringens protease 1 & 24.5 & 2.88 & 0.66 \\
C. perfringens protease 2 & 25.0 & 2.56 & 0.66 \\
Trypsin $(10 \mu \mathrm{g} / \mathrm{ml})$ & 1.73 & 0.02 & 0.46 \\
\hline
\end{tabular}

* See Materials and Methods. 
TABLE II

Toxicities before and after tryptic activation and activation ratios of progenitor toxins

\begin{tabular}{lccc}
\hline \multirow{2}{*}{ Preparation } & \multicolumn{2}{c}{$\mathrm{LD}_{50} / \mathrm{ml}$} & $\begin{array}{c}\text { Activation } \\
\text { ratio }\end{array}$ \\
\cline { 2 - 3 } & Before activation & After activation* & \\
\hline Type E & 75 & 13,000 & 173 \\
Type B (QC)-M & 150 & 140,000 & 933 \\
Type B (Okra)-L & 760 & 120,000 & 157 \\
Type B (Okra)-M & 540 & 190,000 & 352 \\
\hline
\end{tabular}

* Each preparation was treated with trypsin $(10 \mu \mathrm{g} / \mathrm{ml})$ at $35 \mathrm{C}$ for $30 \mathrm{~min}$.

equilibrated with the same buffer. Two toxin peaks were eluted as reported by Kozaki et al. (1974); the first one (L toxin) at or near the void volume of the column and the retarded one ( $M$ toxin) at the same position as that for eluting type $\mathrm{E}$ progenitor toxin (12S). Type E progenitor toxin was purified by the method reported by Kitamura, Sakaguchi and Sakaguchi (1968).

The toxicities before and after tryptic activation and the activation ratio of each progenitor toxin at the concentration utilized to examine for its responses to clostridial proteases are tabulated in Table II.

Assay methods: Activation of progenitor toxin was performed in $0.05 \mathrm{M}$ acetate buffer, $\mathrm{pH}$ 6.0, containing $10 \mathrm{~mm}$ MCE. To $0.1 \mathrm{ml}$ of progenitor toxin, $0.1 \mathrm{ml}$ of an enzyme solution and $0.8 \mathrm{ml}$ of the buffer were added. The reaction mixture was incubated at $35 \mathrm{C}$ for $30 \mathrm{~min}$. The toxicities before and after enzyme treatment in terms of ip $\mathrm{LD}_{50} / \mathrm{ml}$ were estimated by the time-to-death method (Boroff and Fleck, 1966) from the same standard curve prepared with each trypsinactivated progenitor toxin, although the toxicity of unactivated type E progenitor toxin would be overestimated by this method (Sakaguchi, Sakaguchi and Kondo, 1968). The percentage of the toxicity resulting from treatment with a given clostridial protease to that resulting from trypsinization was used to express the activation potency.

Protease activity was measured with heat-denatured casein as substrate by the method of Kunits (1947) with a slight modification. Each 2.0-ml reaction mixture contained $1.0 \mathrm{ml}$ of substrate $(1.0 \%)$ in $0.1 \mathrm{M}$ acetate buffer, $\mathrm{pH} 6.0,0.2 \mathrm{ml}$ of $0.1 \mathrm{M}$ MCE, $0.7 \mathrm{ml}$ of the buffer, and $0.1 \mathrm{ml}$ of an enzyme solution. The reaction mixtures were incubated at $35 \mathrm{C}$ for $30 \mathrm{~min}$ and added with $3.0 \mathrm{ml}$ of $10 \%$ trichloroacetic acid to terminate the reaction. The precipitate was removed by filtration through Toyo filter paper No. 1A; the filtrate was added with Folin phenol reagent according to the method of Lowry et al. (1951) to determine the color developed with acid soluble substances. One unit was defined arbitrarily as the enzyme activity increasing OD at $710 \mathrm{~nm}$ by 1.00 per min.

Amidase activity was assayed according to the method described by Erlanger, Kokowsky and Cohen (1961). The reaction mixture of $1.5 \mathrm{ml}$ consisted of $1.25 \mathrm{ml}$ of $1 \mathrm{~mm}$ substrate (BAPA; $N$-benzoyl-DL-arginine $p$-nitroanilide) in $0.05 \mathrm{M}$ acetate buffer, $\mathrm{pH} 6.0,0.15 \mathrm{ml}$ of $0.1 \mathrm{M} \mathrm{MCE}$, and $0.1 \mathrm{ml}$ of an enzyme solution. The 
reaction mixtures were incubated at $35 \mathrm{C}$ for $30 \mathrm{~min}$ and added with $0.25 \mathrm{ml}$ of $30 \%$ acetic acid to stop the reaction. $p$-Nitroaniline released was measured spectrophotometrically at $410 \mathrm{~nm}$. The activity was expressed in an arbitrary unit defined as the activity liberating I $\mu$ mole of $p$-nitroaniline per min under the specified conditions.

Esterase activity was assayed by the method of Roberts (1958). Each 1.0-ml reaction mixture contained $0.2 \mathrm{ml}$ of $0.1 \mathrm{M}$ substrate (TAME; $p$-toluene sulfonylL-arginine methylester), $0.5 \mathrm{ml}$ of $0.05 \mathrm{M}$ acetate buffer, $\mathrm{pH} 6.0$, containing $0.02 \mathrm{M}$ MCE, $0.1 \mathrm{ml}$ of distilled water, and $0.2 \mathrm{ml}$ of an enzyme solution. The reaction was carried out at $35 \mathrm{C}$ for $30 \mathrm{~min}$. An arbitrary unit was defined as an activity hydrolyzing $1 \mu$ mole of the substrate per min.

\section{RESUlts \\ Responses of Type E Progenitor Toxin}

Type E progenitor toxin responded to all enzyme preparations derived from six different clostridial species; the resulting toxicities were $51-81 \%$ of that attained with trypsin (Table III). On the basis of any of protease, amidase, and esterase activities, the activating potency upon type $\mathrm{E}$ progenitor toxin with any clostridial enzyme was lower than that of trypsin.

Little or no activation was brought about with most enzyme preparations in the presence of $10 \mathrm{~mm} N$-ethylmaleimide (NEM), a sulfhydryl-binding reagent, or $10 \mathrm{~mm}$ ethylenediaminetetraacetic acid (EDTA), a chelating agent. Both enzymes isolated from $C$. perfringens behaved differently; they were inhibited with NEM but not with EDTA. Most clostridial enzymes thus required a reduced condition and some metal(s) for activation of type E progenitor toxin.

\section{Responses of Type B Progenitor Toxin}

In contrast to relatively strong response of type $\mathrm{E}$ progenitor toxin, type $\mathrm{B}$ progenitor toxin responded to much lower extents to the clostridial proteases (Table IV). The lower toxicity was not the result of destruction of the toxin by proteolysis but reflected the relative insensitivity of type $\mathrm{B}$ progenitor toxin to the clostridial proteases including that from the homologous strain, because the subsequent trypsinization brought about a much increased toxicity (Table V).

There was no significant difference in the response between $M$ and $L$ toxins or between the progenitor toxin from the proteolytic strain and that from the nonproteolytic strain.

\section{Some Properties of Clostridial Proteases}

Activities of clostridial proteases upon BAPA and the effects of some inhibitor were investigated. Monoiodo acetate (MIA) and NEM, both at a concentration 
TABLE III

Responses of type E progenitor toxin and effects of NEM and EDTA

\begin{tabular}{lccc}
\hline \multirow{2}{*}{ Protease from } & \multicolumn{3}{c}{ Activation ratio } \\
\cline { 2 - 4 } & None & +NEM $(10 \mathrm{mM})$ & +EDTA $(10 \mathrm{mM})$ \\
\hline C. histolyticum & 81 & $<1.0$ & $\mathrm{ND}^{*}$ \\
C. sporogenes & 75 & $<1.0$ & $<1.0$ \\
C. botulinum type A & 68 & $<1.0$ & 4.1 \\
C. botulinum type B & 65 & $<1.0$ & 2.6 \\
C. botulinum type F & 54 & $\mathrm{ND}$ & $<1.0$ \\
C. perfringens protease 1 & 61 & 3.3 & 47 \\
C. perfringens protease 2 & 51 & $<1.0$ & 44 \\
Trypsin $(10 \mu \mathrm{g} / \mathrm{ml})$ & 100 & $\mathrm{ND}$ & $\mathrm{ND}$ \\
No enzyme & 0.4 & $\mathrm{ND}$ & $\mathrm{ND}$ \\
\hline
\end{tabular}

* Not determined

TABLE IV

Responses of type $B$ progenitor toxins

\begin{tabular}{lccc}
\hline \multirow{2}{*}{ Protease from } & \multicolumn{3}{c}{ Activation ratio } \\
\cline { 2 - 4 } & QC M toxin & Okra M toxin & Okra L toxin \\
\hline C. histolyticum & 2.1 & 2.1 & 2.1 \\
C. sporogenes & 5.0 & 10.2 & 10.2 \\
C. botulinum type A & 3.8 & 7.7 & 1.7 \\
C. botulinum type B & 5.5 & 12.5 & 2.6 \\
C. botulinum type F & 5.3 & 5.3 & 1.7 \\
C. perfringens protease 1 & 0.36 & ND* & 0.5 \\
C. perfringens protease 2 & 0.91 & 5.4 & 0.9 \\
Trypsin $(10 \mu \mathrm{g} / \mathrm{ml})$ & 100 & 100 & 100 \\
No enzyme & 1.4 & 0.9 & 0.3 \\
\hline
\end{tabular}

* Not determined

TABLE V

Tryptic activation of type $B$ progenitor toxin (QC $M$ toxin) after treating with each protease

\begin{tabular}{lcc}
\hline \multirow{2}{*}{ Protease from } & \multicolumn{2}{c}{ Activation ratio } \\
\cline { 2 - 3 } & $\begin{array}{c}\text { With each } \\
\text { protease }\end{array}$ & $\begin{array}{c}\text { Subsequent } \\
\text { trypsinization }\end{array}$ \\
\hline C. histolyticum & 3.1 & 85 \\
C. sporogenes & 5.0 & 109 \\
C. botulinum type A & 3.7 & 100 \\
C. botulinum type B & 5.7 & 107 \\
C. botulinum type F & 7.6 & 78 \\
C. perfringens protease 1 & 0.5 & 80 \\
C. perfringens protease 2 & 1.0 & 63 \\
Trypsin $(10 \mu \mathrm{g} / \mathrm{ml})$ & 100 & $\mathrm{ND}$ \\
\hline
\end{tabular}

* Not determined 
TABLE VI

Effects of some inhibitors on amidase activity

\begin{tabular}{lcccc}
\hline \multirow{2}{*}{ Protease from } & \multicolumn{3}{c}{ Units/ml in the presence of $10 \mathrm{mM}$ MCE } \\
\cline { 2 - 5 } & None & NEM (10 mM) & MIA (10 mM) & EDTA (10 mM) \\
\hline C. histolyticum & 21.0 & 0.30 & 3.30 & 2.60 \\
C. sporogenes & 27.8 & 0.70 & 1.40 & 0.20 \\
C. botulinum type A & 6.30 & 0.30 & 0.40 & 0.20 \\
C. botulinum type B & 6.80 & 0.30 & 0.30 & 0.20 \\
C. botulinum type F & 6.80 & 0.01 & 0.01 & 0.01 \\
C. perfringens protease 1 & 0.98 & 0.09 & 0.12 & 2.70 \\
C. perfringens protease 2 & 1.38 & 0.02 & 0.20 & 2.24 \\
\hline
\end{tabular}

TABLE VII

Effects of $\mathrm{pH}$ on amidase activity

\begin{tabular}{|c|c|c|c|c|c|c|c|c|}
\hline \multirow{3}{*}{ Protease from } & \multicolumn{8}{|c|}{ Units/ml } \\
\hline & \multicolumn{5}{|c|}{$0.1 \mathrm{M}$ acetate buffer } & \multicolumn{3}{|c|}{$0.1 \mathrm{M}$ Tris-HCl buffer } \\
\hline & pH 5.0 & pH 5.5 & $\mathrm{pH} 6.0$ & $\mathrm{pH} 6.5$ & $\mathrm{pH} 7.0$ & $\mathrm{pH} 7.5$ & $\mathrm{pH} 8.0$ & pH 9.0 \\
\hline C. histolyticum & 1.40 & 6.80 & 15.3 & 17.3 & 17.2 & 17.8 & 12.9 & 3.81 \\
\hline C. sporogenes & 2.41 & 9.97 & 25.1 & 31.5 & 32.0 & 30.4 & 12.5 & 2.31 \\
\hline C. botulinum type A & 0.96 & 2.95 & 11.6 & 10.6 & 7.72 & 7.43 & 3.69 & 0.98 \\
\hline C. botulinum type B & 0.85 & 4.41 & 20.2 & 11.6 & 11.1 & 7.47 & 3.86 & 0.67 \\
\hline C. botulinum type $\mathbf{F}$ & 1.00 & 4.00 & 15.4 & 17.6 & 17.0 & 11.7 & 5.61 & 1.11 \\
\hline C. perfringens protease 1 & 0.27 & 1.05 & 1.81 & 1.52 & 1.35 & 1.11 & 0.50 & 0.11 \\
\hline C. perfringens protease 2 & 0.16 & 0.44 & 2. 63 & 1.83 & 1.93 & 1.38 & 0.60 & 0.12 \\
\hline
\end{tabular}

of $10 \mathrm{~mm}$, markedly inhibited the activities of all enzymes except $C$. perfringens proteases 1 and 2 (Table VI). The inhibition of the amidase activity coincided with that of activation of type $\mathrm{E}$ progenitor toxin (Tables III and VI).

The $\mathrm{pH}$ optimum of the enzyme activity was rather broad ranging between pH 6.0 and 7.5 (Table VII). Little or no loss of the activity occurred when the enzymes were stored in the presence of $10 \mathrm{~mm}$ each of $\mathrm{MCE}$ and $\mathrm{CaCl}_{2}$ at $-20 \mathrm{C}$ for a period up to 2 weeks; storage at $20 \mathrm{C}$ under the same conditions resulted in appreciably decreased activity in $24 \mathrm{hr}$.

\section{Discussion}

C. botulinum type $\mathbf{B}$ and $\mathbf{E}$ progenitor toxins responded to apparently heterogeneous sulfhydryl-dependent proteases produced by several clostridial strains, but activation was not so effective as that by trypsin. All the clostridial proteases tested showed preference of activating type $\mathrm{E}$ over type $\mathrm{B}$ progenitor toxin. NEM, an SH-binding reagent, EDTA, a chelating agent, inhibited hydrolysis of synthetic substrate and activation of type $\mathrm{E}$ progenitor toxin. C. histolyticum produces an $\mathrm{SH}$-dependent protease, clostridiopeptidase B or clostripain (Mitchell and Harring- 
ton, 1971). We purified clostripain by the method reported by Mitchell and Harrington (1968) and demonstrated that it activated also only partially type B and E progenitor toxins. It seems that the enzyme prepared from $C$. histolyticum culture by the method reported herein and clostripain are the same. Clostripain differs from trypsin in its marked preference for the arginine over lysine residue, yet it does hydrolyze lysine-containing bonds (Mitchell and Harrington, 1971). The present results, therefore, may point to the possibility that activation involves cleavage of only a lysine-containing bond rather than an arginine-containing one, if activation involves cleavage of a single bond in the progenitor toxin molecule. The common structures of the two fragments of trypsinized type $\mathrm{E}$ toxin $(7 \mathrm{~S})$ and naturally activated type A and B toxins (both 7S) (DasGupta and Sugiyama, 1972c) may suggest that activation involves cleavage of not more than one peptide bond, though there is no proof to show that nicking and activation are the same. A trypsin-like enzyme isolated from pronase (Streptomyces griceus proteases) preferentially hydrolyzes a synthetic lysine ester over an arginine ester and activates type E progenitor toxin even more efficiently than trypsin (Miura, 1974).

The toxins of $C$. botulinum type A and proteolytic type $\mathrm{F}$ strains are activable only when very young cultures are trypsinized, whereas the toxin of a strongly proteolytic type B Okra strain is activable with trypsin even at a late stage of incubation (Iida, 1970). We experienced that type B progenitor toxin purified from strain Okra was activable with trypsin (Kozaki et al., 1974), whereas type F progenitor toxin also from proteolytic Langeland strain was not (Ohishi and Sakaguchi, 1974). An explanation can be given to the discrepancy by the fact that the clostridial sulfhydryl-dependent proteases showed marked preference in activation of type $\mathrm{E}$ over type $\mathrm{B}$ progenitor toxin. The difference may indicate an important difference in molecular structure or configuration between type $\mathrm{B}$ and $\mathrm{E}$ progenitor toxins. A plausible explanation is that the molecular structure or configuration of type $\mathrm{A}$ and $\mathrm{F}$ progenitor toxins are more like that of type $\mathrm{E}$ progenitor toxin. Hence, type $\mathrm{A}$ and $\mathrm{F}$ progenitor toxins are activated very rapidly by the endogenous proteases, while type B progenitor toxin is only partially activated even though the endogenous protease is as active as those of other proteolytic types. Another possible but not very likely interpretation is that the bond(s) cloven in activation of type B progenitor toxin may be qualitatively different from that of other types. DasGupta and Sugiyama (1972b) observed that the protease (TLE) isolated from C. botulinum type B strain Okra activated type E toxin (7S) always to a less extent than did trypsin. They interpreted the observation as cleavage of at least two bonds necessary for full activation. TLE cleaves only an arginyl linkage resulting in incomplete activation and trypsin both arginyl and lysyl bonds resulting in complete activation. This explanation is not very convincing, since SDS electrophoresis of reduced fully activated toxin (7S) disclosed not three but only two fragments (DasGupta and Sugiyama, 1972c).

Neither their results nor ours indicate any qualitative difference in the bond(s) cloven in activation between trypsin and the clostridial proteases nor between type $B$ and $E$ progenitor toxins. Further studies seem necessary to elucidate the preferential activation of type $\mathrm{E}$ over type $\mathrm{B}$ progenitor toxin by clostridial pro- 
teases and the more effective activation achieved by trypsin than by clostridial proteases.

\section{REFERENCES}

Bonventre, P. F. And Kempe, L. L. (1959): Toxicity enhancement of Clostridium butolinum type A and B culture filtrates by proteolytic enzymes. J. Bacteriol., 78, 892-893.

Bonventre, P. F. ANd Kempe, L. L. (1960): Physiology of toxin production by Clostridium botulinum types A and B. IV. Activation of the toxin. J. Bacteriol., 79, 24-32.

Boroff, D. A. AND Fleck, U. (1966): Statistical analysis of a rapid in vivo method for the titration of the toxin of Clostridium botulinum. J Bacteriol., 92, 1580-1581.

DasGupta, B. R. (1971): Activation of Clostridium botulinum type B toxin by an endogenous enzyme. J. Bacteriol., 108, 1051-1057.

DasGupta, B. R. ANd Sugryama, H. (1972a): Isolation and characterization of a protease from Clostridium botulinum type B. Biochim. Biophys. Acta, 268, 719-729.

DasGupta, B. R. And Sugryama, H. (1972b): Role of a protease in natural activation of Clostridium botulinum neurotoxin. Infect. Immunity, 6, 587-590.

DasGupta, B. R. ANd Sugryama, H. (1972c): A common subunit structure in Clostridium botulinum types A, B, and E toxins. Biochem. Biophys. Res. Commun., 48, 108-112.

Duff, J. T., Wright, G. G. And Yarinsky, A. (1956): Activation of Clostridium botulinum type E toxin by trypsin. J. Bacteriol., 72, 455-460.

Erlanger, B. F., Kokowsky, N. and Cohen, W. (1961): The preparation and properties of two new chromogenic substrates of trypsin. Arch. Biochem. Biophys., 95, 271-278.

Holdeman, L. V. (1967): Growth and toxin production of $\mathrm{Cl}$. botulinum type F. p. 176-184. In M. Ingram and T. A. Roberts [ed.]. Botulism 1966. Chapman and Hall, London.

IIDA, H. (1970): Activation of Clostridium botulinum toxin by trypsin. p. 336-340. In M. Herzberg [ed.]. Toxic Micro-organisms. The UJNR Joint Panels on Toxic Micro-organisms and the U.S. Department of the Interior, Washington, D. C.

InUKaI, Y. (1963): Activation of the toxin in the culture of Clostridium botulinum type A. Japan. J. Vet. Res., 11, 87-93.

Kitamura, M., Sakaguchi, S. and Sakaguchi, G. (1968): Purification and some properties of Clostridium botulinum type-E toxin. Biochim. Biophys. Acta, 168, 207-217.

Kozaki, S., Sakagughi, S. And Sakaguchi, G. (1974): Purification and some properties of progenitor toxins of Clostridium botulinum type B. Infect. Immunity, 10, 750-758.

KunITz, M. (1947): Crystalline soybean trypsin inhibitor. II. General properties. J. Gen. Physiol., 30, 291-310.

Lowry, O. H., Rosebrough, N. J., Farr, A. L. and Randall, R. J. (1951): Protein measurement with the Folin phenol reagent. J. Biol. Chem., 193, 265-275.

Mitchell, W. M. and Harrington, W. F. (1968): Purification and properties of clostridiopeptidase B (clostripain). J. Biol. Chem., 243, 4683-4692.

Mitchell, W. M. and Harrington, W. F. (1971): Clostripain. p. 699-719. In P. D. Boyer [ed.]. Enzymes III. Academic Press, New York and London.

MrURA, T. (1974): Isolation and characterization of an esterase active enzyme from pronase with special reference to activation of Clostridium botulinum type $\mathbf{E}$ progenitor toxin. Japan. J. Med. Sci. Biol., 27, 285-296.

Ohishi, I. AND SAKaguchi, G. (1974): Purification of Clostridium botulinum type F progenitor toxin. Appl. Microbiol. 28, 923-928.

Roberts, P. S. (1958): Measurement of the rate of plasmin action on synthetic substrates. J. Biol. Chem., 232, 285-291.

Sakaguchi, G. And Tohyama, Y. (1955a): Studies on the toxin production of Clostridium botulinum type E. I. A strain of genus Clostridium having the action to promote type $\mathbf{E}$ botulinal toxin production in a mixed culture. Japan. J. Med. Sci. Biol., 8, 247-253.

Sakaguchi, G. And Tohyama, Y. (1955b): Studies on the toxin production of Clostridium botulinum type E. II. The mode of action of the contaminant organisms to promote toxin production of type E organisms. Japan. J. Med. Sci. Biol., 8, 255-262.

Sakaguchi, G., Sakaguchi, S. ANd Kondo, H. (1968): Rapid bioassay for Clostridium botulinum type $\mathbf{E}$ toxins by intravenous injection into mice. Japan. J. Med. Sci. Biol., 22, 369-378. 